\title{
Waste from the cement industry - a component of sealing grouts
}

\section{Introduction}

The production of cement produces a byproduct in the form of small amounts of dust captured by the dedusting system of the kiln.

The preferred and most common method of using cement kiln dust (CKD) is its re-use in the cement production process in amounts which do not cause deterioration of the quality of the final product. Complete recycling of CKD into the production process is technologically possible but not practiced due to the strict limits on the permissible amounts of alkali in the mix of raw materials (Maslehuddin et. al. 2008). Cement kiln dust (CKD) can be used as a raw material in the production of building materials such as bricks, lightweight aggregate, mortar, concrete, and bituminous mixtures. In civil engineering, it can be used to stabilize clay soils (Rahman et al. 2007).

A high density of $\mathrm{CaO}$ makes it a very effective material for stabilization and hygienization of sewage sludge, while in agriculture it may be used as a component of fertilizers and animal feeds (Bożym et al. 2011). Dust from cement kilns like fluidized fly ash can also potentially be used as a material for mineral sequestration of $\mathrm{CO}_{2}$ (Uliasz-Bocheńczyk 2009; Uliasz-Bocheńczyk and Mokrzycki 2011, 2013).

Grout additives containing CKD are an example of a very interesting application of the aforementioned dust (Stryczek et al. 2009). The grouts are widely used in drilling; they can

* D.Sc. Eng., ** M.Sc. Eng., AGH University of Science and Technology, Krakow, Poland; e-mail:aub@agh.edu.pl 
be used for sealing the spaces between shroud tubes and for preventing leakage of drilling fluid. In civil engineering they can be used for the construction of municipal and industrial waste landfills, especially in the case of storage of toxic waste. In the hydropower industry, they can be used for minimizing or eliminating flow paths. In communication engineering they can be used for strengthening purposes, and for the demolition of bridge abutments and piers.

Fluidized bed fly ashes are now used mainly in building materials underground mining in the form of aqueous suspensions, as well as in road works (Emitor 2013). These wastes may also be used as a stabilizer for soils (Filipiak 2011, 2013).

This article presents the results of studies on the physicochemical properties of grouts based on fly ash from hard coal combustion in fluidized bed boilers, with the addition of cement kiln dust from a dry process cement plant, specifically as employed in mining technologies.

\section{Characteristics of dust from the cement industry}

Cement kiln dust (CKD) is a particulate material consisting of particles of clinker, calcium, and other alkaline chemicals. It is very diverse in terms of chemical composition and grain size (Maslehuddin et al. 2008). The share of individual compounds depends largely on the raw materials used in the cement production technology, the fuel type, and the method of dust removal. Most frequently, dust contains unreacted raw material components, clinker dust, ash from fuels containing sulfates, halides, and other volatile compounds.

Table 1. Chemical composition of CKD [\%]

Tabela 1. Skład chemiczny pyłów cementowych [\%]

\begin{tabular}{|c|c|c|c|c|c|}
\hline Component & $\begin{array}{c}\text { Maslehuddin } \\
\text { et al. 2008 }\end{array}$ & $\begin{array}{c}\text { Aidan and } \\
\text { Trevor 1995 }\end{array}$ & $\begin{array}{c}\text { Collins and } \\
\text { Emery 1983 }\end{array}$ & $\begin{array}{c}\text { Peethamparan et al. } \\
2008\end{array}$ & $\begin{array}{c}\text { Lachemi et al. } \\
2010\end{array}$ \\
\hline $\mathrm{SiO}_{2}$ & 17.1 & 15.84 & 14.5 & $11.91-16.42$ & 13.1 \\
\hline $\mathrm{Al}_{2} \mathrm{O}_{3}$ & 4.24 & 3.57 & 4.10 & $2.17-4.66$ & 5.3 \\
\hline $\mathrm{Fe}_{2} \mathrm{O}_{3}$ & 2.89 & 2.76 & 2.00 & $1.71-2.34$ & 2.3 \\
\hline $\mathrm{CaO}$ & 49.3 & 63.76 & 40.5 & $37.35-55.00$ & 58.1 \\
\hline $\mathrm{MgO}$ & 1.14 & 1.93 & 1.55 & $1.24-2.68$ & 3.3 \\
\hline $\mathrm{SO}_{3}$ & 78.2 & 1.65 & 6.50 & $5.8-14.62$ & 10.6 \\
\hline $\mathrm{Na}_{2} \mathrm{O}$ & 3.84 & 0.33 & 0.44 & $0.17-0.81$ & 0.7 \\
\hline $\mathrm{K}_{2} \mathrm{O}$ & 2.18 & 2.99 & 4.66 & $1.43-7.0$ & 2.8 \\
\hline $\mathrm{Cl}$ & 6.9 & 1.09 & - & $0.35-3.26$ & - \\
\hline L.O.I & 15.8 & 5.38 & 22.9 & $3.92-29.63$ & 3.1 \\
\hline
\end{tabular}


(Bożym 2011). CKD from the dry process contains a higher proportion of calcium than dust derived from the wet process (Siddique 2006). The composition of the dust from cement kilns, according to several authors, is presented in Table 1.

CKD contains considerable amounts of alkali and trace metals, such as arsenic, cadmium, lead, mercury, thallium, selenium, zinc, and radionuclides, which are typically at a concentration of less than 0.05 wt. \%. This factor is conditioned by the type of pulverized material and the recirculation in the kiln system. These are highly alkaline dusts characterized by a pH of about 12 (Bożym 2011).

\section{Research methodology}

Grouts must have specific physico-chemical properties dependent on the conditions of use. Selecting the right sealing grout is not an easy task and, therefore, it is not possible to indicate a universal formulation; but grouts for injection should have the following technological parameters (Stryczek and Gonet 2000):

- suitable rheological properties,

- suitable mechanical properties,

- sufficient flexibility under given conditions and over a sufficiently long period,

- resistance to aggressive waters and micro-organisms,

- ability to bond in high humidity,

- adjustable time of injection and binding,

no toxic substances,

- non flammability,

- the simplicity of the technology of preparing them under difficult field conditions,

- easily transporting the components to the operation site,

- relatively low cost of implementation,

- specified range of penetration of the grout in the rock mass,

- adequate adhesion for sealing the surface,

- low shrinkage as well as the possibility of use of expansive material.

Grouts typically consist of the following components (Stryczek and Gonet 2000):

- binder,

- solvent,

- agents modifying the properties of the fresh and hardened sealing grout,

fillers.

Common cements, slag-alkali binder, and calcareous fly ash are most frequently used as a binder. Depending on the application, various modifying additives and fillers are used.

The aim of the laboratory tests was to determine the effect of CKD on the selected properties of fresh and hardened grouts made from fluidized bed fly ash. The tested grouts were prepared using a water/cement ratio ranging from 1.1 to 1.4 for the three adopted contents of CKD of 25,50 , and $75 \%$. 
Fresh grouts were subjected to basic research; the following parameters were determined:

- density,

- fluidity,

- bleeding rate,

- setting time.

In order to investigate the effect of CKD on the hardened grout, the compressive strength of the samples with the lowest water/solid ratio was examined. Laboratory tests for the measurement of rheological parameters of fresh sealing grouts were carried out according to the following standards: PN G-11011:1998 Mining - Materials for Backfilling and Caulking of Cavings - Requirements and Tests and PN-EN 196-1 Methods of testing cement.

$\mathrm{X}$-ray diffraction and thermogravimetric analyses of phase composition were also performed. The measurements were performed using a Netzsch STA 449F3 Jupiter thermal analyzer and a QMS 403C Aëolos for routine analysis of gases. The measurements were performed under a dynamic synthetic air atmosphere with a flow of $40 \mathrm{ml} / \mathrm{min}$. The rate of temperature increase was $10^{\circ} \mathrm{C} / \mathrm{min}$. Sample weight was approximately $130 \mathrm{mg}$. X-ray diffraction studies were performed on a Philips PW1050/70 diffractometer in the measuring range $5-65^{\circ} 2 \Theta \mathrm{CuK}_{\alpha}{ }^{1}$.

The aqueous extracts of the tested waste were prepared using the procedure described in the Polish standard PN-EN 12457-2:2006 Characterization of Waste - Leaching Compliance Test for Leaching of Granular Waste Materials and Sludges - Part 2. One stage batch test at a liquid to solid ratio of $10 \mathrm{dm}^{3} / \mathrm{kg}$ for materials with a particle size below $4 \mathrm{~mm}$ (without or with size rduction).

\section{Characteristics of materials for the production of sealing grouts}

This study used fly ash from hard coal combustion in a atmospheric fluidized bed boiler (AFBCC - fly ashes) (Table 2; Fig. 1) as a grout binder. To determine the effect of dust as a modifier, CKD from a dry process cement plant has been selected (Table 2; Fig. 1).

The CKD used in the study was characterized by a high content of $\mathrm{CaO}(55.2 \%)$ and $\mathrm{Cl}^{-}(4 \%)$, while the fluidized bed fly ash was characterized by a high content of $\mathrm{SiO}_{2}(43.9 \%)$ (Table 2).

Fluidized bed combustion fly ash was characterized by a Blaine specific surface area of $5,900 \mathrm{~cm}^{2} / \mathrm{g}$, while CKD was $9,300 \mathrm{~cm}^{2} / \mathrm{g}$.

\footnotetext{
1 The analysis of pollutant leachability, the values of $\mathrm{pH}, \mathrm{XRD}$ and TGA analysis were conducted in the Department of Building Materials of the Faculty of Materials Engineering and Ceramics at the AGH University of Science and Technology.
} 
Table 2. Chemical composition of materials used for the research [\%]

Tabela 2. Skład chemiczny materiałów wykorzystanych w badaniach [\%]

\begin{tabular}{|c|c|c|}
\hline Component & AFBCC - fly ash & CKD \\
\hline $\mathrm{SiO}_{2}$ & 43.9 & 16.8 \\
\hline $\mathrm{Al}_{2} \mathrm{O}_{3}$ & 12.7 & 3.9 \\
\hline $\mathrm{Fe}_{2} \mathrm{O}_{3}$ & 12.0 & 1.9 \\
\hline $\mathrm{CaO}$ & 12.1 & 55.2 \\
\hline $\mathrm{MgO}$ & 0.40 & 1.5 \\
\hline $\mathrm{SO}_{3}$ & 3.99 & 1.7 \\
\hline $\mathrm{Na}_{2} \mathrm{O}$ & 4.30 & 0.3 \\
\hline $\mathrm{K}_{2} \mathrm{O}$ & 4.1 & 4.1 \\
\hline $\mathrm{Cl}^{-}$ & 0.58 & 4.0 \\
\hline $\mathrm{LOI}$ & b.d. & 19.7 \\
\hline Density $\left[\mathrm{Mg} / \mathrm{m}^{3}\right]$ & 2.6 & 3.1 \\
\hline
\end{tabular}

The results of the grain size distribution analysis of the tested CKD and fluidized bed combustion fly ash showed that the most frequent grain size was in the range of $0-5 \mu \mathrm{m}$ (Fig. 1).

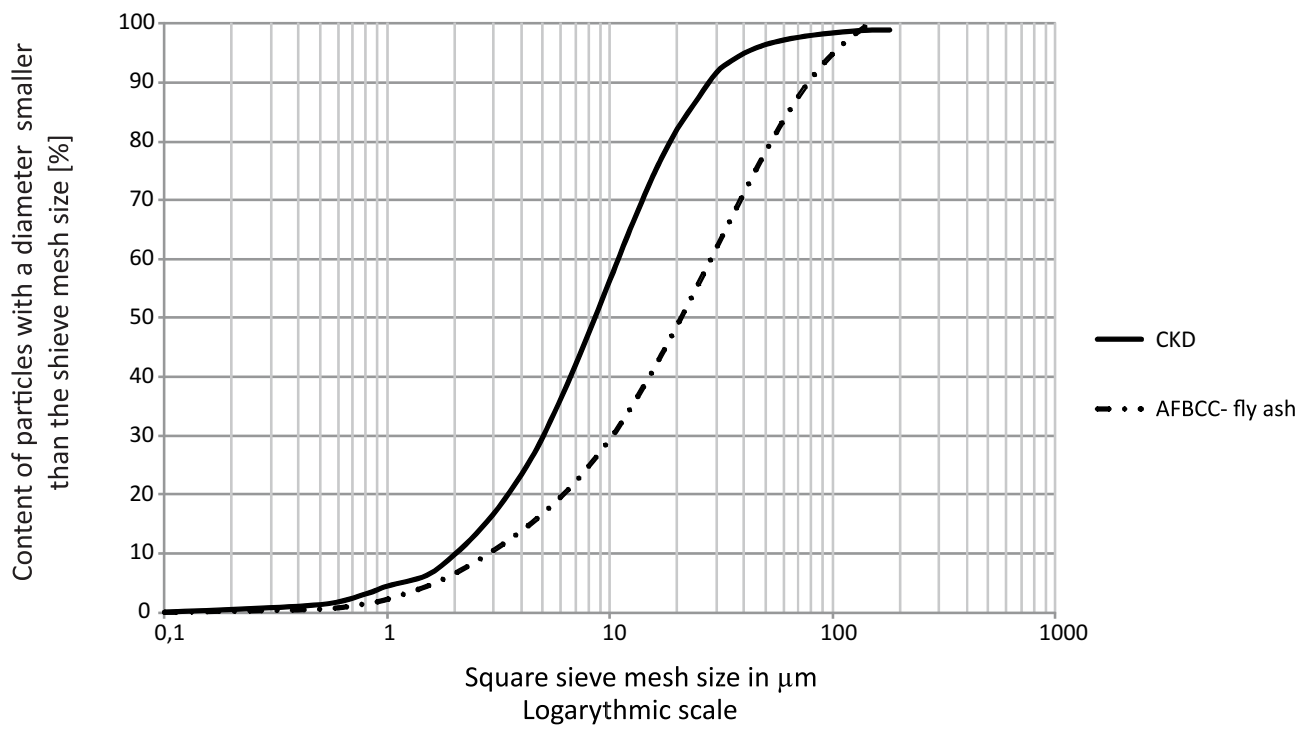

Fig. 1. Size distribution curve of AFBCC - fly ashes and CKD

Rys. 1. Krzywa składu ziarnowego popiołu fluidalnego i pyłu cementowego 


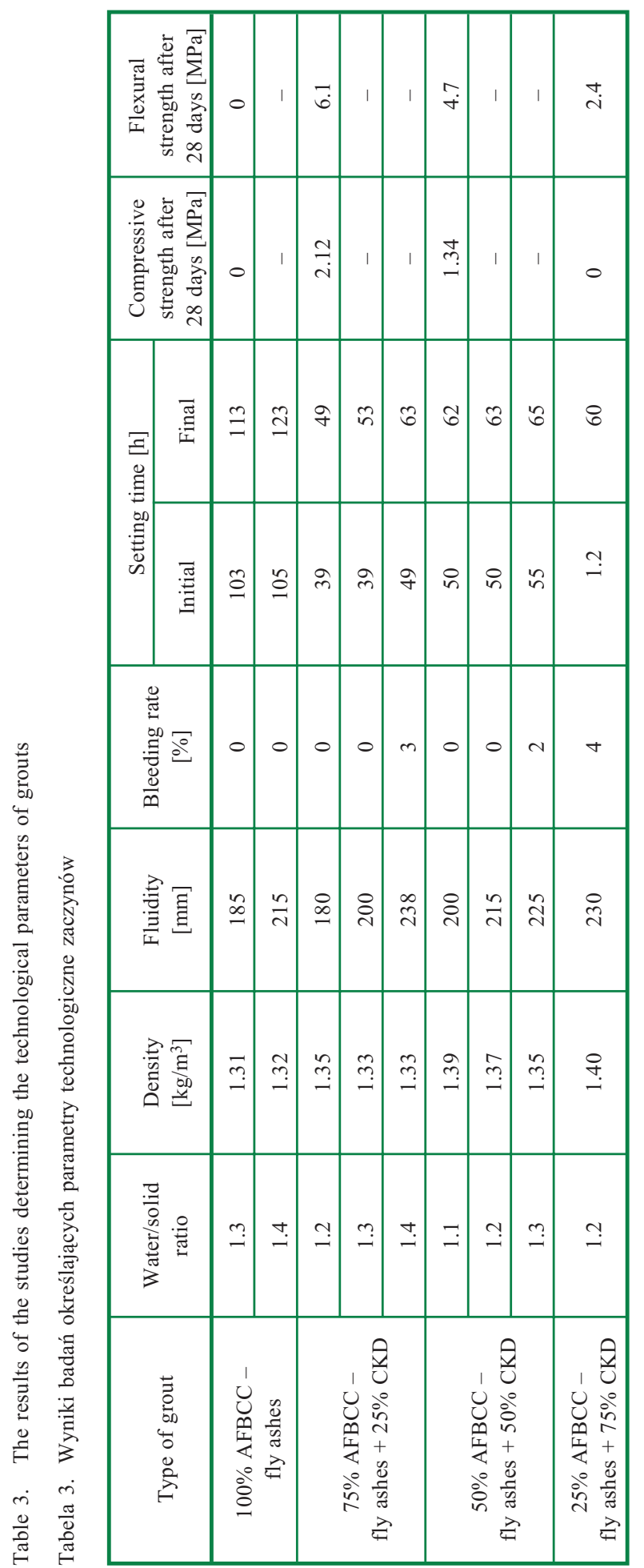




\section{Research results}

\subsection{Technological parameters}

of cement-fly ash grouts with the addition of CKD

The research showed that the addition of cement kiln dust affects the technological properties of cement-fly ash grouts (Table 3). The most important parameter determining the use of grouts is fluidity. When choosing the water-binder ratios, the study referred to the degree of required fluidity for grouts in the range between 18 and $24 \mathrm{~cm}$ (Stryczek and Gonet 2000). The fluidity of the tested grouts increases with the addition of CKD, which may be due to a greater surface area of the dust. The biggest bleeding ratio, 4\%, was observed in the grout with the greatest share of CKD, amounting to $75 \%$.

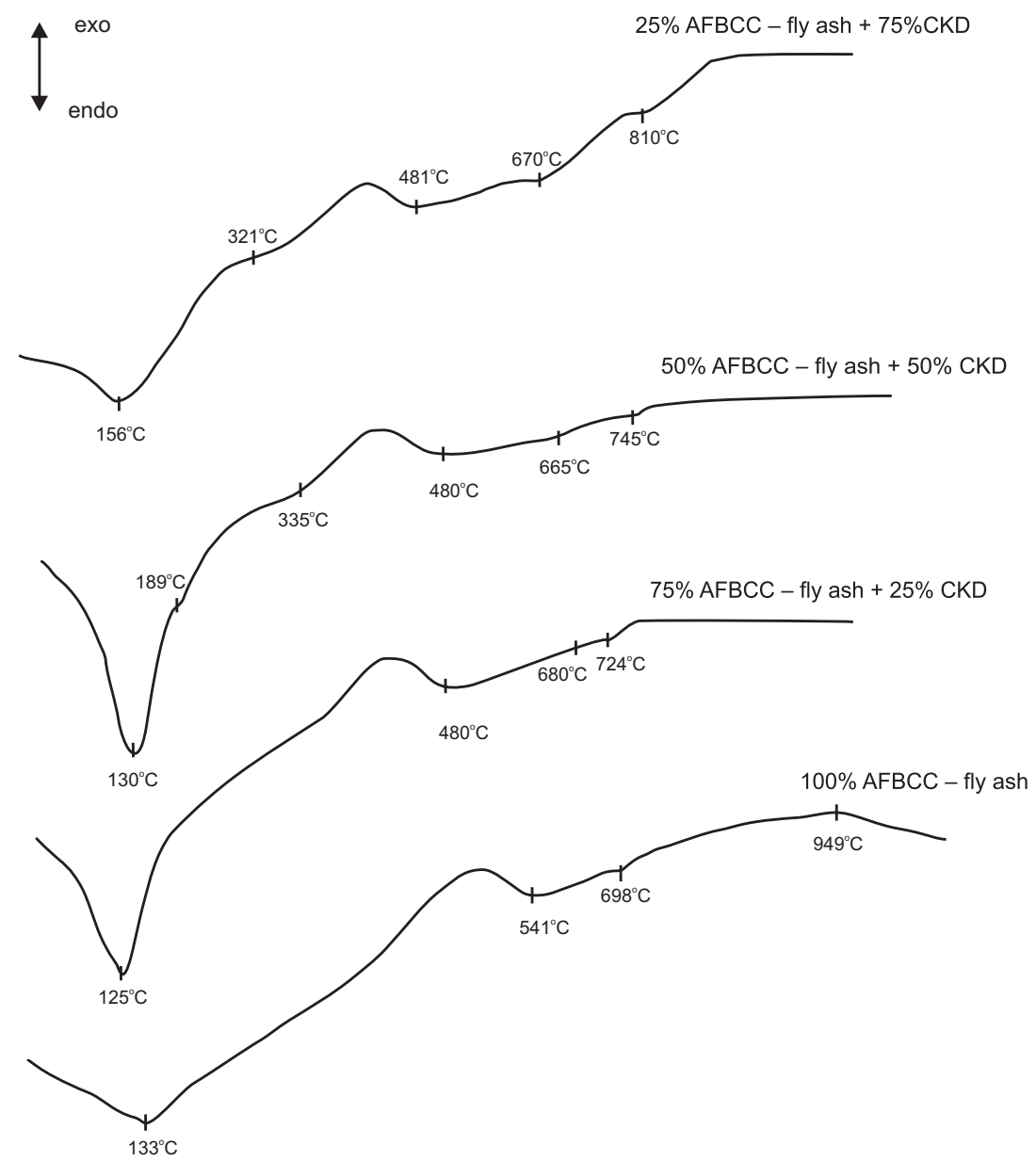

Fig. 2. DTA curves of grout used for the research

Rys. 2. Krzywe DTA badanych zaczynów 


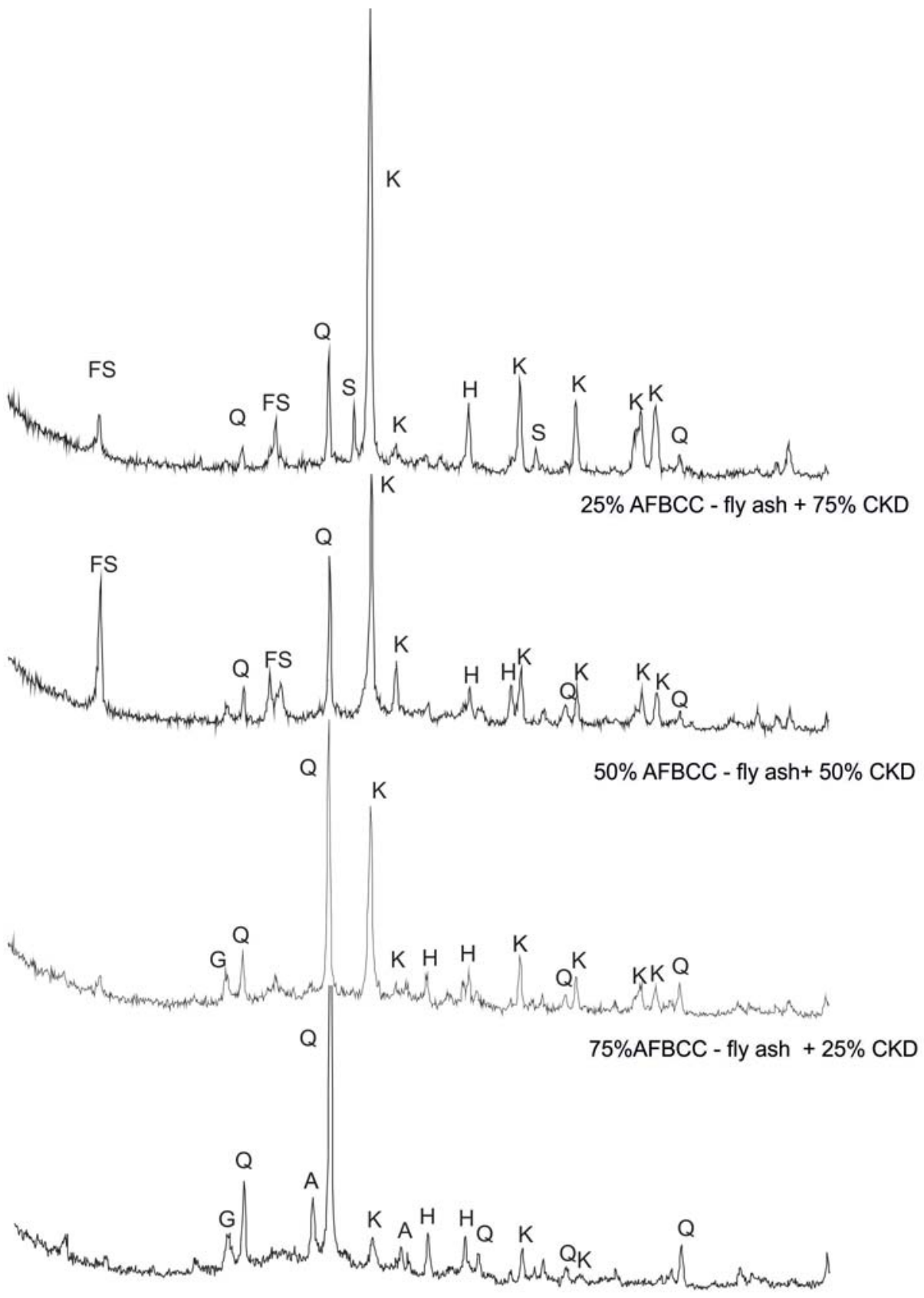

$100 \%$ AFBCC - fly ash

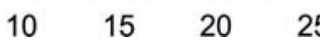

Fig. 3. Diffractograms of grouts used for the research

$\mathrm{K}$ - calcite, Q - quartz, A - anhydrite, H - hematite, G - gypsum, FS - Friedel's salt, S - sylvite Rys. 3. Dyfraktogramy badanych zaczynów 
Setting time is a very important parameter used in the selection of the proper grout recipe. All of the mixtures containing CKD are characterized by extended setting time. The setting time increases along with increasing amounts of CKD. Lastly, the introduction of dust causes a slight increase in the compressive strength of the tested grouts.

\subsection{Phase composition of the grouts}

All of the tested samples showed endothermic effects with a maximum at $125-156^{\circ} \mathrm{C}$, which can be related to the presence of gypsum or C-S-H (Giergiczny 2006). The grouts with a higher content of particulate matter demonstrated endothermic effects with a maximum at $321{ }^{\circ} \mathrm{C}$ (grout - fluidized bed combustion ash $50 \%+\mathrm{CKD} 50 \%$ ) and $335^{\circ} \mathrm{C}$ (grout fluidized bed combustion ash $25 \%+\mathrm{CKD} 75 \%$ ) associated with dehydration of the $3 \mathrm{CaO} \cdot \mathrm{Al}_{2} \mathrm{O}_{3} \cdot \mathrm{CaCl}_{2} \cdot 10 \mathrm{H}_{2} \mathrm{O}$ phase, which was not present in the grouts with $100 \%$ ash content and $25 \%$ dust content (Fig. 2).

The endothermic effect observed for all curves with a maximum at about $660^{\circ} \mathrm{C}$ is associated with decarbonatization of complex compounds with carbonates, which precedes a smaller effect with a maximum around $700-900^{\circ} \mathrm{C}$ indicating the decomposition of calcium carbonate (Ubbriaco and Calabrese 2000). The endothermic effect with a maximum at about $480-541^{\circ} \mathrm{C}$ is associated with the presence of portlandite.

The results of X-ray studies (Fig. 3) showed that the main phases in clean grouts prepared with ash from the fluidized bed combustion of coal include calcite, quartz, anhydrite, hematite, and gypsum. This is confirmed by the results of other authors (Giergiczny 2006; Iwanek et al. 2008; Rajczyk et al. 2006).

The introduction of dust resulted in the appearance of phases containing chlorine the $3 \mathrm{CaO} \cdot \mathrm{Al}_{2} \mathrm{O}_{3} \cdot \mathrm{CaCl}_{2} \cdot 10 \mathrm{H}_{2} \mathrm{O}$ phase - Friedel's salt, and $\mathrm{KCl}-$ sylvite, which is due to its high content in CKD.

\subsection{Leachability}

The leachability of impurities from grouts is a very important factor in the possibility of their use. To determine the effect of the addition of CKD on the leachability of chemical impurities, the composition and characteristics of the water eluate of grouts were examined. The results were compared with the requirements of the Polish standard PN-G-11011:1998 (Table 4).

The leachability of impurities of the tested grouts meets the requirements of the standards for $\mathrm{As}, \mathrm{Cd}, \mathrm{Cu}, \mathrm{Hg}, \mathrm{Pb}, \mathrm{Cr}(\mathrm{III})$, and sulfides. When it comes to sulphates, the standard is met by the grouts containing dusts. Increasing the dust content increased the leachability of chloride until the permissible value of the Polish standard PN-G-11011:1998 was exceeded by the grouts containing 50 and $75 \%$ dust. The $\mathrm{pH}$ value in all cases exceeded the value permissible by the standard. 
Table 4. Leaching of chemical impurities from grouts used for the research

Tabela 4. Wymywalność zanieczyszczeń z badanych zaczynów

\begin{tabular}{|c|c|c|c|c|c|}
\hline \multirow[b]{2}{*}{ Type of designation } & \multirow[b]{2}{*}{$\begin{array}{c}\text { AFBCC - } \\
\text { fly ash }\end{array}$} & \multicolumn{3}{|c|}{ Type of grout } & \multirow{2}{*}{$\begin{array}{c}\text { Limit values } \\
\text { of leachability } \\
\text { in the } \\
\text { PN-G-11011 } \\
\text { standard }\end{array}$} \\
\hline & & $\begin{array}{c}75 \% \text { AFBCC - } \\
\text { fly ash }+25 \% \\
\text { CKD }\end{array}$ & $\begin{array}{c}50 \% \text { AFBCC - } \\
\text { fly ash }+50 \% \\
\text { CKD }\end{array}$ & $\begin{array}{c}25 \% \text { AFBCC - } \\
\text { fly ash }+75 \% \\
\text { CKD }\end{array}$ & \\
\hline As $\left[\mathrm{mg} / \mathrm{dm}^{3}\right]$ & $<0.05$ & $<0.0001$ & $<0.0001$ & $<0.0001$ & 0.1 \\
\hline $\mathrm{Cd}\left[\mathrm{mg} / \mathrm{dm}^{3}\right]$ & $<0.005$ & $<0.00022$ & 0.00003 & $<0.00003$ & 0.02 \\
\hline $\mathrm{Cu}\left[\mathrm{mg} / \mathrm{dm}^{3}\right]$ & 0.06 & 0.00012 & 0.00011 & 0.0009 & 0.5 \\
\hline $\mathrm{Hg}\left[\mathrm{mg} / \mathrm{dm}^{3}\right]$ & $<0.05$ & $<0.00003$ & 0.000044 & $<0.00003$ & 0.05 \\
\hline $\mathrm{Pb}\left[\mathrm{mg} / \mathrm{dm}^{3}\right]$ & $<0.05$ & 0.0001 & 0.0034 & 0.0144 & 0.5 \\
\hline $\mathrm{Cr}(\mathrm{VI})\left[\mathrm{mg} / \mathrm{dm}^{3}\right]$ & 0.71 & 0.10 & 0.25 & 0.24 & 0.5 \\
\hline $\mathrm{Cr}(\mathrm{III})\left[\mathrm{mg} / \mathrm{dm}^{3}\right]$ & 0.04 & 0.08 & 0.00 & 0.02 & 0.1 \\
\hline Sulphates $\left[\mathrm{mg} / \mathrm{dm}^{3}\right]$ & 1589 & 206 & 272 & 259 & 500 \\
\hline Chloride $\left[\mathrm{mg} / \mathrm{dm}^{3}\right]$ & 35 & 798 & 1981 & 1950 & 1000 \\
\hline Sulfides $\left[\mathrm{mg} / \mathrm{dm}^{3}\right]$ & $<0.1$ & $<0.1$ & $<0.1$ & $<0.1$ & $<0.1$ \\
\hline $\mathrm{pH}$ & 12.5 & 12.3 & 12.5 & 13.1 & $6.0-12.0$ \\
\hline
\end{tabular}

The addition of dust had little impact on the leachability of impurities. A reduction in leachability as a result of the addition of dust was identified for $\mathrm{Cd}, \mathrm{Cu}, \mathrm{Hg}$, $\mathrm{Cr}(\mathrm{V})$, and $\mathrm{Cr}(\mathrm{III})$, which can be explained by immobilization of C-S-H (Deja 2002). The addition of dust caused an increase in the leachability of chlorides related to their high content in the studied dust, despite part of them binding in the new phases - the $3 \mathrm{CaO} \cdot \mathrm{Al}_{2} \mathrm{O}_{3} \cdot \mathrm{CaCl}_{2} \cdot 10 \mathrm{H}_{2} \mathrm{O}$ phase - Friedel's salt, and sylvite $-\mathrm{KCl}$.

\section{Conclusions}

Grouts used as a binder, or as an additive or filler, may include various kinds of mineral wastes, making the economic use of certain mineral wastes possible. AFBCC - fly ash, thanks to their high reactivity, can be used as a binder in grouts in which CKD can be used as an additive. A wide range of tests were performed for a complete analysis of the impact of the addition of dust on the technological and physico-chemical characteristics of grouts based on fluidized bed combustion fly ashes.

On the basis of laboratory testing and analysis of the obtained results it can be concluded that an increased concentration of CKD in grouts based on fluidized bed combustion fly ash favors the following:

- increased fluidity, 
- extended setting time,

- a slight increase in the strength of the tested materials.

The analyses indicated the presence of calcite, quartz, anhydrite, hematite, portlandite and gypsum and probably C-S-H in the phase compositions of the tested grouts. The grouts containing 50 and $75 \%$ dust showed the presence of the $3 \mathrm{CaO} \cdot \mathrm{Al}_{2} \mathrm{O}_{3} \cdot \mathrm{CaCl}_{2} \cdot 10 \mathrm{H}_{2} \mathrm{O}$ phase, which was not found in grouts based on fluidized bed combustion fly ash and those containing $25 \%$ dust. The grouts containing $75 \%$ dust showed the presence of sylvite.

A problem encountered was the high $\mathrm{pH}$, which - if not reduced - rules out use in mining technologies. The increased leachability of chlorides can be regulated by using lower amounts of dust.

These examination will be repeated using ash other than AFBCC - fly ash in order to obtain the proper $\mathrm{pH}$ and leachability of impurities to meet the requirements of the Polish standard PN G-11011:1998 Mining - Materials for Backfilling and Caulking of Cavings Requirements and Tests. These results will also be the basis for further examinations of grouts using other AFBCC - fly ash and dust for a better understanding of their properties and to obtain mixtures that meet the aforementioned standard.

Artykut opracowano w ramach badań statutowych AGH $\mathrm{nr}$ 11.11.100.482

\section{REFERENCES}

Aidan, C. and Trevor, C. 1995. Cement kiln dust. Concrete, pp. 40-42.

Bożym, M. 2011. Alternative methods of cement and lime dusts utilization, especially with sewage sludge pretreatment. Prace Instytutu Ceramiki i Materiałów Budowlanych 8, pp. 59-68 (in Polish).

Bras et al. 2010 - Bras, A., Henriques, F. and Cidade, M.T. 2010. Effect of environmental temperature and fly ash addition in hydraulic lime grout behavior. Construction and Building Materials 24, pp. 1511-1517.

Collins, R.J. and Emery, J.J. 1983. Kiln dust-fly ash systems for highways bases and sub-bases. Federal Highway Administration, Report No. FHWA/RD-82/167, Washington DC.

Deja, J. 2002. Immobilization of $\mathrm{Cr}^{6+}, \mathrm{Cd}^{2+}, \mathrm{Zn}^{2+}$ and $\mathrm{Pb}^{2+}$ in alkali-actived slag binders. Cement and Concrete Research 32, pp. 1971-1979.

Emitor 2013. Emission of environmental pollution in power plants and in combined heat and power plants. Published by The Energy Market Agency, Warsaw, Poland (in Polish).

Filipiak, J. 2011. Fly ash in construction industry. Strength tests of soil stabilized with mixture of ash and cement. Annual Set The Environment Protection - Rocznik Ochrona Środowiska 13, pp. 1043-1054 (in Polish).

Filipiak, J. 2013. Application of Combustion By-products as a Stabilizer for Organic Soils. Annual Set The Environment Protection - Rocznik Ochrona Środowiska 15, pp. 1153-1163 (in Polish).

Giergiczny, Z. 2006. Rola popiołów lotnych wapniowych i krzemionkowych w kształtowaniu właściwości wspótczesnych spoiw budowlanych i tworzyw cementowych. Wydawnictwo Politechniki Krakowskiej, Monografia nr 325, Kraków (in Polish).

Iwanek et al. 2008 - Iwanek, P., Jelonek, I. and Mirkowski, Z. 2008. Preliminary research on fly ash from the fluidal boiler in the context of its development. Gospodarka Surowcami Mineralnymi-Mineral Resources Management 24(4), pp. 91-104 (in Polish) .

Lachemi et al. 2010 - Lachemi, M., Sahmaran, M., Hossain, K.M.A., Lotfy, A. and Shehata, M. 2010. Properties of controlled low-strength materials incorporating cement kiln dust and slag. Cement \& Concrete Composites 32, pp. 623-629. 
Maslehuddin et al. 2008 - Maslehuddin, M., Al-Amoudi, O.S.B., Shameem, M., Rehman, M.K. and Ibrahim, M. 2008. Usage of cement kiln dust in cement products - Research review and preliminary investigations. Construction and Building Materials 22, pp. 2369-2375.

Peethamparan et al. 2008 - Peethamparan, S., Olek, J. and Lovell, J. 2008. Influence of chemical and physical characteristics of cement kiln dusts (CKDs) on their hydration behavior and potential suitability for soil stabilization. Cement and Concrete Research 38, pp. 803-815.

Rahman et al. 2007 - Rahman, M. K., Rehman, S. and Al-Amoudi, O.S.B. 2007. Literature Review On Cement Kiln Dust Usage in Soil And Waste Stabilization and Experimental Investigation, IJRRAS7, pp. 77-87.

Rajczyk et al. 2004 - Rajczyk, K., Giergiczny, E. and Glinicki, M.A. 2004. Use of DTA in the investigations of fly ashes from fluidized bed boilers. Journal of Thermal Analysis and Calorimetry 77, pp. 165-170.

Saiyouri et al. 2008 - Saiyouri, N., Bouasker, M. and Khelidj, A. 2008. Gas permeability measurement on injected soils with cement grout. Cement and Concrete Research 38, pp. 95-103.

Siddique, R. 2006. Utilization of cement kiln dust (CKD) in cement mortar and concrete - an overview. Resources, Conservation and Recycling 48, p. 315-338.

Stryczek et al. 2009 - Stryczek, S., Gonet, A. and Czapik, P. 2009. Developing technological properties of sealing slurries with the use of cement kiln. Wiertnictwo Nafta Gaz 26(1-2), pp. 345-356.

Stryczek, S. and Gonet, A. 2000. Geoengineering. Studia, Rozprawy, Monografie nr 71, Wyd. IGSMiE, Kraków (in Polish).

Ubbriaco, P. and Calabrese, D. 2000. Hydration behavior of mixtures of cement and fly ash mixtures with high sulphate and chloride content. Journal of Thermal Analysis and Calorimetry 61, pp. 615-623.

Uliasz-Bocheńczyk, A. and Dziewański, J. 2001. Injection slurries applicable to the protection of the natural environment. Nowoczesne Techniki i Technologie Bezwykopowe 1, pp. 58-62 (in Polish)

Uliasz-Bocheńczyk, A. 2009. $\mathrm{CO}_{2}$ mineral sequestration in selected wastes Studia, Rozprawy, Monografie nr 153, Wyd. IGSMiE, Kraków (in Polish).

Uliasz-Bocheńczyk, A. and Mokrzycki, G. 2013. Mineral sequestration of $\mathrm{CO}_{2}$ with the use of energy waste an attempt to estimate the Polish potential. Gospodarka Surowcami Mineralnymi - Mineral Resources Management 29(3), pp. 180-189 (in Polish).

Uliasz-Bocheńczyk, A. and Mokrzycki, G. 2011. Possible applications of energy waste for mineral sequestration of $\mathrm{CO}_{2}$. Annual Set The Environment Protection - Rocznik Ochrona Środowiska 13, pp. 1591-1604 (in Polish).

ODPADY Z PRZEMYSLU CEMENTOWEGO - SKLADNIK ZACZYNÓW INIEKCYJNYCH

Słowa kluczowe

zaczyny iniekcyjne, pyły z produkcji cementu, popioły fluidalne

Streszczenie

Pył cementowy jest odpadem z procesu produkcji cementu. Część powstałych w trakcie produkcji cementu pyłów trafia do powtórnego wykorzystania w procesie, jednak pod warunkiem, że nie zawierają one składników mogących obniżyć jakość końcowego produktu. Z uwagi na znaczny udział tlenku wapnia, pyły mogą być stosowane także w ochronie środowiska do: neutralizacji kwaśnych ścieków, stabilizacji i nawożenia gleb czy do unieszkodliwiania osadów ściekowych. Jednym z kierunków gospodarczego wykorzystania tego typu odpadów jest stosowanie ich jako dodatków do zaczynów iniekcyjnych. 
W pracy przedstawiono wyniki wstępnych badań świeżych i stwardniałych zawiesin wykonanych na bazie pyłu cementowego oraz popiołu fluidalnego ze spalania węgla kamiennego w aspekcie zastosowania ich jako materiału do sporządzania zaczynów iniekcyjnych. Badaniom poddano zaczyny sporządzone z popiołów fluidalnych z wprowadzonymi pyłami cementowymi w ilości: 25, 50 i 57\%.

Wprowadzenie pyłów cementowych do zaczynów sporządzonych z popiołów fluidalnych wpłynęło na ich podstawowe parametry technologiczne poprzez: wzrost rozlewności, wydłużenie początku i końca czasu wiązania oraz wzrost wytrzymałości.

Badane zaczyny charakteryzują się podobnymi składami fazowymi, jednak dodatek pyłów spowodował pojawienie się fazy $3 \mathrm{CaO} \cdot \mathrm{Al}_{2} \mathrm{O}_{3} \cdot \mathrm{CaCl}_{2} \cdot 10 \mathrm{H}_{2} \mathrm{O}$ oraz $\mathrm{KCl}$.

Przeprowadzone oznaczanie wymywalności wykazało, że badane zaczyny nie spełniają wymagań normy PN-G-11011:1998 Górnictwo - Materiaty do podsadzki zestalanej i doszczelniania zrobów Wymagania i badania w zakresie wymagań dla pH oraz zawartości chlorków po dodaniu 50 i 75\% pyłów.

\section{WASTE FROM THE CEMENT INDUSTRY - A COMPONENT OF SEALING GROUTS}

$$
\text { Key words }
$$

sealing grouts, dust from cement production, fluidized bed fly ashes

\section{Abstract}

Cement kiln dust is a waste product of the cement production process. Part of the dust generated during the burning of Portland cement clinker may be reused in the process, provided it does not contain components that might reduce the quality of the final product. Given the large proportion of calcium oxide, the dust can also be used for purposes of environmental protection in neutralization of acid wastewater, stabilization and fertilization of soil, or disposal of sewage sludge. One of the methods of the economic utilization of this type of waste is its use as a grout additive.

This paper presents the preliminary results of research into fresh and hardened grouts made on the basis of cement kiln dust - as well as ash from fluidized bed combustion of hard coal - used as a material for the preparation of sealing grouts. The grouts prepared from fluidized bed fly ash and cement kiln dust, in the proportions of 25,50 , and $57 \%$, were examined.

The introduction of cement kiln dust into grouts prepared from fluidized bed fly ashes affected the grouts' basic technological parameters, increasing their fluidity, lengthening the setting time, and increasing their strength.

The studied grouts are characterized by similar phase compositions; however, the addition of dust has resulted in the formation of the $3 \mathrm{CaO} \cdot \mathrm{Al}_{2} \mathrm{O}_{3} \cdot \mathrm{CaCl}_{2} \cdot 10 \mathrm{H}_{2} \mathrm{O}$ phase - Friedel's salt, and sylvite $-\mathrm{KCl}$.

A leachability determination has shown that the tested grouts do not meet the requirements of the Polish standard PN G-11011:1998 Mining - Materials for Backfilling and Caulking of Cavings Requirements and Tests regarding the requirements for $\mathrm{pH}$ and chloride content after adding 50 and $75 \%$ dust content. 
